University of Nebraska - Lincoln

DigitalCommons@University of Nebraska - Lincoln

The Nebraska Educator: A Student-Led Journal Department of Teaching, Learning and Teacher

Education

3-2016

Fostering Metacognition in K-12 Classrooms: Recommendations for Practice

Markeya S. Peteranetz

University of Nebraska-Lincoln, peteranetz@unl.edu

Follow this and additional works at: https://digitalcommons.unl.edu/nebeducator

Part of the Teacher Education and Professional Development Commons

Peteranetz, Markeya S., "Fostering Metacognition in K-12 Classrooms: Recommendations for Practice" (2016). The Nebraska Educator: A Student-Led Journal. 31.

https://digitalcommons.unl.edu/nebeducator/31

This Article is brought to you for free and open access by the Department of Teaching, Learning and Teacher Education at DigitalCommons@University of Nebraska - Lincoln. It has been accepted for inclusion in The Nebraska Educator: A Student-Led Journal by an authorized administrator of DigitalCommons@University of Nebraska - Lincoln. 


\title{
Fostering Metacognition in K-12 Classrooms: Recommendations for Practice
}

\author{
Markeya S. Peteranetz
}

\begin{abstract}
This article makes the case for why it is important for educators to intentionally foster students' metacognition. Metacognition is often defined as thinking about thinking, but it is more complete to describe it as including knowledge, awareness, and control of one's own cognition and human cognition in general. Two primary components of metacognition, knowledge of cognition and regulation of cognition, are presented and described with regard to learning contexts. Metacognition grows as part of cognitive development and can also be further enhanced through instruction at all levels of schooling. Research that indicates metacognition can be increased through instruction and is associated with academic achievement is reviewed. Steps for embedding metacognition instruction are described and principles for incorporating metacognition instruction into classroom instruction are presented. Metacognition instruction, including strategy instruction, may be either implicit or explicit, and can and should be incorporated into typical classroom instruction.
\end{abstract}


Keywords: Metacognition, strategies, strategy instruction, embedded instruction

Genre: Theoretical/Conceptual

Tmagine a middle school where eighth grade American history is taught by four different teachers: Ms. Pierson, Mr. Samuels, Mr. Brown, and Ms. Andrews. All the eighth-grade students are learning about the United States' founding fathers, but these teachers differ in how they help students learn the material. Ms. Pierson tells her students to read the chapter from the text book and gives them class time to do so. Down the hall, Mr. Samuels also gives his students class time to read the chapter, but he gives his students a worksheet to complete as they read. He tells them, "Fill this sheet out as you read, and turn it in when you are done. We will talk about it tomorrow and see how well you understand the chapter." The worksheet contains a matrix organizer (as shown in Figure 1) that provides space for the students to record important information about the founding fathers. The top row of the matrix contains all the founding fathers who are discussed in the chapter, and the left-most column contains categories that can be used to compare the founding fathers.

In the next classroom, Mr. Brown gives students the same matrix organizer worksheet and time to read the chapter in class. However, before Mr. Brown lets his students begin working he tells them, "Let's look at the different topics and categories in this matrix organizer. You can see that

\begin{tabular}{|l|l|l|l|l|}
\hline & George Washington & Thomas Jefferson & Benjamin Franklin & John Adams \\
\hline Birthdate & & & & \\
\hline Death date & & & & \\
\hline Nickname & & & & \\
\hline Profession(s) & & & & \\
\hline Offices held & & & & \\
\hline Documents signed & & & & \\
\hline
\end{tabular}

Figure 1. A sample matrix-organizer for learning about the Founding Fathers. 
the top row lists several founding fathers such as George Washington, Thomas Jefferson, and Benjamin Franklin. You can also see the left column lists categories such as birthdate, death date, and nicknames. Now that we know what is on the matrix organizer, let's look at the chapter. Follow along with me as I start reading the section about George Washington. 'George Washington was born on February 22, 1732 in Westmoreland County, Virginia.' I remember that birthdate is a category in my matrix, so I am going to write 'February 22, 1732' in the cell that connects George Washington and birthdate. As you read, look for information that corresponds to the topics and categories in the matrix. By the end of the chapter you should have filled all the cells."

Ms. Andrews also has her students complete a similar matrix organizer worksheet while completing the reading in class. The matrix she provides is identical to the one that Mr. Samuels and Mr. Brown used, except that the one Ms. Andrews provides does not include "professions," "offices held," and "documents signed" in the list of categories. When providing the matrix, she explains, "This table is called a matrix. It has rows and columns that can be used to organize any information that compares two or more topics along one or more categories in a way that makes it easier to remember information and see relationships within that information. I have already provided the topics and some categories for you. When creating a matrix, we put the topics on top. As you can see, the topics of this chapter include many of our founding fathers, such as George Washington, Thomas Jefferson, and Benjamin Franklin. The categories are in the leftmost column, and they are the characteristics used to compare the topics. You can see I have given you a few sample categories: birth date, death date, and nicknames. You can also see that I left some of the boxes in that column blank, because you need to generate a few categories on your own. As you read the text, try to find the details that intersect topics and categories. For example, one of George Washington's nicknames is the Father of His Country. Such details go in the box that is at the intersection of the relevant topic (e.g., George Washington) and category (e.g., nickname). After you read each paragraph, be sure to ask yourself, 'Can I put anything from that paragraph in my matrix?' If you pause after each paragraph, you will be more likely to capture all of the important details in your matrix. Once you have finished reading the chapter and have completed your matrix, you will have an excellent study tool that you can use to study for the next test. It should be easy for you to see the similarities 
and differences among these founding fathers, and seeing those relationships will help you better understand the roles they played in our country's history." After Ms. Andrews finishes her explanation, the students begin reading and completing their matrices.

The four teachers at this middle school are teaching the same material, but the extent to which their methods support student learning differs considerably. Ms. Pierson did the least: she only provided students class time to read. She did not provide any additional support for her students' learning, and it is completely up to the students to learn from the reading. Mr. Samuels helped students learn by providing the matrix organizer. This instructional tool helped students extract and organize important information from the reading, but Mr. Samuels did not show them how to use it, tell them why it is a beneficial tool, or provide any additional support that would help the students use this type of tool in the future. Mr. Brown provided the same instructional tool, but he showed students how to learn by modeling how to use it. He also prompted his students to look at the structure of the matrix organizer before reading so that they could use it efficiently. However, Mr. Brown failed to explain why it is a beneficial tool or provide additional information that would help the students use this type of tool independently in the future. Ms. Andrews provided the same type of instructional tool, but she supported students' present and future learning. She taught students how to use it, why it is a helpful learning tool, and how they can create a matrix independently in the future. Moreover, Ms. Andrews prompted students to monitor their organizer use periodically by pausing to ask themselves questions about how they could use it. Ms. Andrews supported students' learning the most because she taught students how to learn by providing explicit instruction on how, why, and when to use matrix organizers.

Mr. Brown and Ms. Andrews demonstrate different ways teachers can teach students how to learn by fostering metacognition, that is, providing instruction related to knowledge, awareness, and control of one's thinking. Mr. Brown modeled metacognition and prompted students to use metacognition without expressly acknowledging it, a practice referred to as implicit metacognition instruction. Ms. Andrews explicitly taught students how and why to use the matrix-learning strategy, explained why it is beneficial, and pointed out how they could use their organizer in the future. Ms. Andrews's practices reflect what is known as explicit metacognition instruction. Broadly, metacognition instruction is instruction that is intentionally designed to encourage the use of metacognition. Metacognition 
enables students to strategically apply skills and strategies across learning contexts so that they can learn effectively and independently. Metacognition instruction fosters metacognition and can help students develop as independent learners.

This article makes the case for why it is important for educators to foster students' metacognition intentionally like Mr. Brown and Ms. Andrews did. First, I provide a conceptual overview of metacognition. Second, I describe the role of metacognition in education, including the relationship between metacognition and academic achievement and factors that can lead to changes in metacognition. Third, I describe metacognition instruction and review research related to metacognition instruction. Finally, I provide recommendations for educators interested in fostering metacognition.

\section{Conceptual Overview of Metacognition}

Metacognition is frequently given the terse definition, "thinking about thinking" or "cognition about cognition." The term was introduced by Flavell (1979), and his early ideas have been analyzed and expanded upon in the 35 years since. A more recent conceptualization of metacognition describes it as including knowledge, awareness, and control of one's own cognition and human cognition in general (Tarricone, 2011). Although there is not complete consensus in the literature about what is and is not metacognition, many theorists and researchers recognize that metacognition includes both knowledge of cognition and regulation of cognition (Schraw, 1998; Tarricone, 2011), also referred to as metacognitive knowledge and metacognitive skills (Veenman \& Spaans, 2005; Veenman, Van Hout-Wolters, Afflerbach, 2006), respectively. Figure 2 provides a conceptual framework for frequently identified components of metacognition.

Knowledge of cognition includes what a person knows about strategies, his own thought processes, and people in general as cognitive beings (Pintrich, 2002). It includes the sub-components of declarative, procedural, and conditional knowledge (Schraw, 1998 Schraw, Crippen, Hartley, 2006; Veenman, 2011). Declarative knowledge includes knowledge about one's own cognitive abilities and factors that influence learning and performance. For example, most first graders recognize that it is more difficult to remember how to spell a ten-letter word than a three-letter word: 


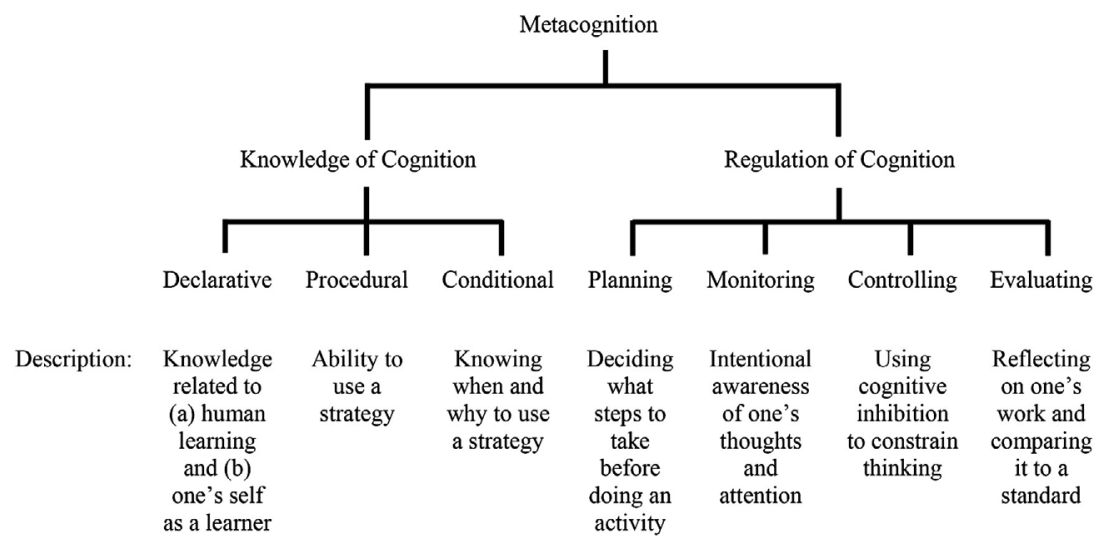

Figure 2. Theoretical framework of metacognition.

the length of the word influences one's ability to remember its spelling. Procedural knowledge is knowledge of how to carry out tasks and strategies. Procedural knowledge enables high school students to create an effective outline before writing a paper or take notes during a lecture. Conditional knowledge refers to the understanding of when and why to use a particular strategy; that is, knowing and recognizing the conditions under which a strategy should be used. An algebra student uses conditional knowledge when deciding to underline important information and then check her work after completing a complex word problem, but not use those strategies when completing a problem that can be solved mentally.

The different types of knowledge of cognition often are used in concert as an individual completes a task. As an example, imagine Emma is reading a novel for her seventh grade English class. Emma knows that she frequently gets confused while reading novels because she has difficulty remembering details about each individual character. She knows that like most novels, this new novel will likely have several characters, and the author will likely describe the physical appearance and personality of each character as well as any important relationships among characters. Emma decides to create a graphic organizer that can be used as a reference when she gets confused while reading or when her class is discussing the book. On a piece of paper, Emma creates a matrix by writing the main characters' names in one row toward the top of the paper and 
listing a few categories for comparison like "appearance" and "relationship to others" down the left-hand side. As she reads, she adds more categories and characters' names, and she fills in the cells of the matrix. She includes a page number each time she puts a note in a cell so she will be able to find the information again, if necessary.

Each aspect of metacognitive knowledge is found in this example. Emma's understanding of her weakness as a reader exemplifies declarative knowledge. Her recognition of the appropriateness and usefulness of a graphic organizer for comparing story characters indicates she has conditional knowledge about the matrix strategy. Her ability to use the matrix strategy reveals she has procedural knowledge. Emma's decision to use page number references reflects her declarative knowledge of general human cognition, because she recognizes that it is unlikely that a person will remember the exact location of a single detail within a novel.

Regulation of cognition makes up the "active" side of metacognition (see Figure 2). This group of skills includes processes such as planning, monitoring, controlling, and evaluating cognition (Schraw, 1998; Veenman \& Spaans, 2005). Planning cognition includes things such as goal setting, pre-selecting strategies, and determining the order in which steps are completed. Students who set goals related to the number of books or pages they will read in a week or create a plan for completing a term project are engaged in planning. Monitoring cognition is awareness of comprehension, thought processes, and strategy use while completing a task (Schraw \& Moshman, 1995). Monitoring allows learners to recognize when they do not understand what they are reading, and it also allows them to use strategies flexibly. Controlling cognition includes processes such as managing attentional resources, inhibiting undesired responses, and constraining thoughts (Zimmerman, 2000). Students who are able to control their cognition are able to ignore potential distractions such as classmates' conversations and can keep their focus on the task at hand. Evaluating cognition includes detecting and correcting errors, comparing outcomes to goals, reflecting on performance, and gauging the efficiency of one's learning (Schraw, 1998). For example, a senior English student is engaged in evaluation when he searches for logical flaws in his argumentative paper, and a fourth-grade student may engage in evaluation by check that she has written complete sentences. Dividing regulation of cognition into these four processes makes it apparent that regulation of cognition can be used before, during, and after the focal cognitive activity (Zimmerman, 2000). 
To illustrate the different components of regulation of cognition, consider Jamal, a student who is writing a report about a current United States senator for his eighth-grade social studies class. His teacher allows students to choose the senator they write about, and he has provided a few general guidelines that the report should cover. Each student's report should include information on the senator's schooling, work before becoming a senator, and accomplishments while in office. Students may include other topics that they believe are important or interesting. After Jamal selects his senator, he decides to do some preliminary reading so he can start planning his paper. While reading, he monitors his understanding and recognizes that he cannot make sense of much of the information about the senator's work in Congress. Jamal then searches the Internet to look up acronyms and jargon he does not understand. Once he has gathered some information, Jamal continues planning by creating an outline that will guide his writing. Jamal does not like to write. Therefore, as he works on his paper, he controls his attention by removing possible distractions from his work area. After completing his paper, Jamal evaluates his work by reading through it to check for errors and to compare his writing to the outline he prepared.

\section{Metacognition in Education}

Metacognition plays a large role in educational settings, and consequently has been the subject of a great deal of research in educational psychology. Research has consistently shown that metacognition is positively related to academic achievement (Labuhn, Zimmerman, \& Hasselhorn, 2010; Pintrich, 2002; Swanson, 1990; Veenman, Wilhelm, Beishuizen, 2004), and it is one of the greatest influences on academic performance (Schraw, 1998; van der Stel \& Veenman, 2010; Veenman \& Spaans, 2005; Veenman et al., 2006; Wang, Haertel, \& Walberg, 1990). Wang, Haertel, \& Walberg (1990) conducted a meta-review to determine which variables had the strongest influence on learning outcomes. They concluded that metacognition has a stronger, more consistent relationship with academic outcomes than virtually any other variable that has been researched, including student demographic variables, students' prior knowledge, student-teacher interactions, and socioeconomic status. Metacognition is associated with achievement outcomes ranging from elementary students' 
reading achievement (Jacobs \& Paris, 1987) to college students' overall achievement (Young \& Fry, 2012).

Research has also shown that changes in metacognitive abilities can result from both development (Krebs \& Roebers, 2010; van der Stel \& Veenman, 2010; Veenman et al., 2004) and instruction (Hilden \& Pressley, 2007; Huff \& Nietfeld, 2009; Moely et al., 1992; Pape, Bell, \& Yetkin, 2003; Ramdass \& Zimmerman, 2008; Veenman, 2013). Flavell (1992) suggested that the emergence of metacognition is connected to traditional Piagetian stages of development. Piaget's theory outlined cognitive development in terms of changes in the way an individual interacts with and reasons about the world. He argued that developmental stages are characterized by the types of mental operations one is capable of completing. In Piaget's theory, the most advanced stage of cognitive development is the formal-operational stage, which is believed to begin around 11 or 12 years of age. The formal-operational stage is characterized by the ability to use deductive reasoning and the ability to perform complex, abstract mental operations (Moshman, 2011). Flavell (1992) argued that formaloperational reasoning requires metacognitive control. Researchers have yet to determine if metacognition precedes formal-operational reasoning or vice versa, but they believe there is a connection between the two.

\section{Changes Due to Development}

A general developmental perspective of metacognition is supported by research that has found age-related increases in metacognition across students ranging from third grade through college (Jacobs \& Paris, 1987; Krebs \& Roebers, 2010; Veenman \& Spaans, 2005; Veenman et al., 2004). In their study of the relationship between metacognition, intelligence, and development, Veenman and colleagues (2004) looked across age groups to compare students' learning and use of metacognition on complex, computer-based inductive learning tasks. They found that students' use of metacognitive skills increased with age and contributed positively to task performance. In another study examining the relationship between metacognition and development, Krebs and Roebers (2010) investigated testtaking strategies and confidence judgments among students between the ages of 8 and 12. Students watched a short informational video and were later tested over its content. The testing process had three steps. Students first answered test questions, then gave a confidence rating for each of 
their answers, and finally crossed out any answers they believed were incorrect. The researchers found that all students were able to reliably differentiate between their own correct and incorrect answers for low difficulty test items, but that older students (11- and 12-year-olds) were better than younger students (8- and 9-year-olds) at differentiating between correct and incorrect answers for high difficultly test items. It appears that children already have some metacognitive monitoring ability by age 8 , but that it continues to develop with age.

\section{Changes Due to Instruction}

Even though an individual's use of metacognition might increase as a result of normal cognitive development, there is evidence that metacognition can also be improved through instruction. Research has found that students receiving explicit instruction in metacognitive knowledge and skills improve both their metacognitive abilities (Hilden \& Pressley, 2007; Huff \& Nietfeld, 2009; Jacobs \& Paris, 1987; Moely et al., 1992; Pape, Bell, \& Yetkin, 2003; Ramdass \& Zimmerman, 2008; Veenman, 2013) and their academic achievement (Haller, Child, \& Walberg., 1988; Csíkos, \& Steklács, 2010; Schraw, 1998). In one study investigating the efficacy of metacognition-based interventions, students' reading comprehension and mathematics achievement improved following a two-month intervention where fourth-grade students learned about and practiced planning, monitoring, and evaluation strategies (Csíkos \& Steklács, 2010). Among other things, students were taught how to activate prior knowledge when reading and how to create a mental model of the situation when working on mathematics problems. Teachers provided unscripted explicit metacognition instruction that was embedded in reading and mathematics lessons. Pre-test to post-test gains in achievement were significantly greater for students involved in the intervention than for students in a control group. That is, the metacognition instruction was more beneficial than traditional reading and mathematics instruction. Similarly, Hargrove and Nietfield (2015) found that incorporating extended metacognitive training into a college course lead to increases in students' metacognition-increases that were not seen in students taking a similar course that did not include the metacognitive training.

In their meta-analysis of studies examining metacognitive instruction of reading comprehension, Haller, Child, and Walberg (1988) concluded 
that metacognitive skills training might have the greatest impact for middle-school aged students, a notion further supported by a later metaanalysis conducted by Dignath and Büttner (2008). Most students begin middle school when they are either 11 or12 years old, the ages at which formal-operational thinking usually first appears. It is not surprising then that metacognitive training is particularly beneficial for individuals who are developing the mental capacity for such thinking.

\section{Research on Metacognition Instruction}

The term metacognition instruction refers to instruction that is designed to build metacognitive knowledge, introduce and develop metacognitive skills, and help students develop a habit of using metacognition. That is, it is instruction with "built in" supports for students' metacognition. Quantitative research provides evidence that metacognition instruction rarely happens in the classroom (Clift, Ghatala, Naus, \& Poole, 1990; Dignath-van Ewijk, Dickhäuser, \& Büttner, 2013; Dignath-van Ewijk \& van der Werf, 2012; Hamman, Berthelot, Saia, \& Crowley, 2000; Kistner, Rakoczy, Otto, Dignath-van Ewjik, Büttner, \& Klieme, 2010; Moely et al., 1992). Studies using self-report methodology have found that few elementary or secondary teachers report integrating any metacognitive instruction into their teaching (Clift, et al.,1990; Dignath-van Ewijk, \& van der Werf, 2012). For example, Clift and colleagues (1990) found that elementary and secondary teachers rarely integrate explicit strategy instruction (defined in the next section) into their teaching, and when they do they often fail to infuse metacognitive knowledge into their instruction. Other studies involving observations of teachers at the elementary and secondary levels have supported these findings (Dignath-van Ewijk et al., 2013; Durkin, 1978; Hamman, Berthelot, Saia, \& Crowley, 2000; Kistner et al., 2010; Moely et al., 1992; Veenman, 2011). For example, Hamman and colleagues (2000) videotaped middle school teachers as they taught three separate lessons throughout a semester. The lessons were $30 \mathrm{~min}-$ utes long, and each lesson was segmented into 30-second units for coding (therefore each lesson consisted of 60 segments). The researchers found that less than $7 \%$ of segments contained an instance of metacognitive instruction. Similarly, Kistner et al. (2010) found that secondary mathematics teachers in Germany, on average, provided between one and two 
metacognitive strategy instructions during a 45-minute lesson. Dignathvan Ewijk et al., (2013) used both self-report and observation to determine how much metacognition instruction teachers included in seventh grade mathematics classes. Observations revealed that teachers on average provided fewer than four metacognition instructions during a 45-minute period. Additionally, there was no correlation between observed metacognition instruction and teachers' self-reports of metacognition instruction. This finding has at least two possible explanations: either teachers and researchers have different ideas of what constitutes metacognition instruction, or teachers do not accurately estimate their metacognition instruction. Overall, these studies indicate that little metacognition instruction takes place in $\mathrm{k}-12$ classrooms.

A few studies have examined how teachers foster metacognition from a qualitative perspective (Perry, 1998; Perry \& VandeKamp, 2000; Perry VandeKamp, Mercer, \& Nordby, 2002). Perry and her colleagues studied metacognition instruction in elementary school classrooms. When not involved in relevant professional development, some teachers incorporated frequent metacognition instruction into their teaching, and some rarely or never incorporated metacognition instruction (Perry, 1998). However, while working with researchers in a focused professional development program, teachers frequently used explicit strategy instruction, reflection activities, and classroom discussions involving knowledge of cognition (Perry \& VandeKamp, 2000; Perry et al., 2002). For example, two different teachers involved in the professional development program ended each reading lesson with a "sharing circle." In the sharing circle students talked about things they learned about themselves as readers as well as strategies that helped them during the lesson (Perry et al., 2002). This activity builds students' declarative knowledge of cognition (Row 1 of Figure 2) by making self-knowledge and knowledge of relevant strategies explicit. The frequent use of metacognition instruction described by Perry and her colleagues (Perry, 1998; Perry \& VandeKamp, 2000; Perry et al., 2002) indicates that metacognition instruction might occur more frequently in some settings than in others, particularly when teachers receive training on how to intentionally foster metacognition. However, research overall indicates that metacognition instruction tends to be rare unless it is intentionally incorporated into instruction. 


\section{Recommendations for Fostering Metacognition}

There are many things teachers can do to foster metacognition (Joseph, 2009; Paris \& Paris, 2001; Paris \& Winograd, 2003; Pintrich, 2002; Schraw, 1998; Zumbrunn, Tadlock, \& Roberts, 2011), all of which belong to one of two broad categories: implicit instruction or explicit instruction. Figure 3 shows a taxonomy of metacognition instruction, including the purpose and examples of each instruction type. The two types of metacognition instruction, implicit and explicit, should be viewed as complementary alternatives and not opposites on a continuum.

\begin{tabular}{|c|c|c|c|c|}
\hline & & Metacognition & Instruction & \\
\hline & Implic & & Explicit & \\
\hline & Prompting & Modeling & Direct Instruction & Teaching Benefits \\
\hline Purpose: & $\begin{array}{l}\text { Encourages or } \\
\text { reminds students } \\
\text { to engage } \\
\text { metacognition }\end{array}$ & $\begin{array}{l}\text { Shows students } \\
\text { metacognition in } \\
\text { action }\end{array}$ & $\begin{array}{l}\text { Provides students with } \\
\text { declarative, } \\
\text { procedural, and/or } \\
\text { conditional knowledge }\end{array}$ & $\begin{array}{l}\text { Provides motivation for } \\
\text { acquiring new strategies } \\
\text { and using metacognition }\end{array}$ \\
\hline $\begin{array}{l}\text { Math } \\
\text { Example: }\end{array}$ & $\begin{array}{l}\text { "How did you get } \\
\text { your answer?" }\end{array}$ & $\begin{array}{l}\text { "I know that word } \\
\text { problems are hard } \\
\text { for me, so the first } \\
\text { thing I am going to } \\
\text { do is draw a picture } \\
\text { that represents the } \\
\text { problem I am trying } \\
\text { to solve." }\end{array}$ & $\begin{array}{l}\text { "One strategy you can } \\
\text { use for multiplying } \\
\text { binomials is called } \\
\text { FOIL. It stands for } \\
\text { first, outside, inside, } \\
\text { last, and it will help } \\
\text { you remember to } \\
\text { multiply all the terms } \\
\text { in the expression." }\end{array}$ & $\begin{array}{l}\text { "If you are aware of } \\
\text { what steps you are using } \\
\text { to solve those problems } \\
\text { and can articulate them, } \\
\text { it will be easier for you } \\
\text { to figure out where your } \\
\text { error is when you get an } \\
\text { incorrect answer." }\end{array}$ \\
\hline $\begin{array}{l}\text { Music } \\
\text { Example: }\end{array}$ & $\begin{array}{l}\text { "What part of this } \\
\text { song do you think } \\
\text { is the most } \\
\text { difficult for you to } \\
\text { play?" }\end{array}$ & $\begin{array}{l}\text { "I forgot that we } \\
\text { have three flats in } \\
\text { the key signature, } \\
\text { and I played E } \\
\text { natural instead of } E \\
\text { flat. I am going to } \\
\text { write in the } \\
\text { accidental next to } \\
\text { that note so I do not } \\
\text { forget again." }\end{array}$ & $\begin{array}{l}\text { "Before you begin to } \\
\text { play a piece of music } \\
\text { for the first time, you } \\
\text { should look at the } \\
\text { tempo, time signature, } \\
\text { key signature, dynamic } \\
\text { levels, and any } \\
\text { accidentals that appear } \\
\text { in the song." }\end{array}$ & $\begin{array}{l}\text { "Being able to hear your } \\
\text { instrument separate } \\
\text { from all the others helps } \\
\text { you know if you're in } \\
\text { tune and blending with } \\
\text { the rest of the ensemble. } \\
\text { If everyone can hear } \\
\text { themselves and make } \\
\text { adjustments when } \\
\text { needed, the overall } \\
\text { quality of our playing } \\
\text { will increase." }\end{array}$ \\
\hline
\end{tabular}

Figure 3. Taxonomy of metacognition instruction. 
Implicit instruction occurs when the nature of instruction or related activities makes it likely students will be metacognitive, without necessarily focusing on the "how" or "why" of using metacognition in that context. This includes modeling or prompting the use of metacognition without expressly acknowledging or discussing it (Dignath-van Ewjik et al., 2013; Kistner et al., 2010), like Mr. Brown's instruction in the opening scenario. For example, when a teacher says to the class, "If the paragraph does not make sense to you the first time, reread it," he is prompting students to monitor their comprehension and apply a corrective strategy if necessary. The teacher is reminding students to use metacognition without explicitly teaching them how or why to do so. Similarly, prompts may be given in the form of a question, such as when a teacher asks a student, "How did you come to that conclusion?" The question prompts the student to work back through his thoughts and become explicitly aware of them. Elementary students can be prompted to indicate how well they have understood a lesson or a reading passage with questions such as, "Can you explain it to me in your own words?” These types of prompts provide students the opportunity to pause and reflect on their own understanding and thought processes. Similarly, teachers can model cognition by thinking aloud while demonstrating skills for students. For example, a high school history teacher could demonstrate how to read and critique a primary source by reading a document aloud and verbalizing his thoughts related to the credibility of the source and any author biases that are evident. Because many aspects of comprehension, problem solving, and other important skills happen internally, learners can benefit from hearing an expert articulate thoughts related to processes that are typically internal.

Explicit instruction takes place when attention is drawn directly to the "how" or "why" of using metacognition. Usually, this takes the form of the teacher pointing out, explaining, or discussing the benefits of metacognition (Dignath-van Ewjik et al., 2013; Kistner et al., 2010), like Ms. Andrews did in the opening scenario. For example, a teacher may say, "Planning your paper before you write can help you to generate better quality ideas, and it will make it easier for you to determine the best order for presenting those ideas. One way to do this is to write out your ideas and organize them into an outline." This teacher is describing why planning is a helpful activity and describing steps the students can use to plan successfully. Discussing the benefits of metacognition is particularly important because doing so motivates students to acquire these 
new strategies or thinking skills (Veenman et al., 2006). If the teacher continues and provides direct instruction related to creating an outline that will facilitate the writing process, the students are more likely to be successful in using the outlining strategy. Additionally, instruction that addresses both procedural and conditional knowledge will enable students to use the strategy independently in the future because they will know how to use the strategy as well as when the strategy is most helpful. As a different example, elementary teachers can talk to students about factors that influence learning such as individual strengths and weaknesses, the difficulty of a task, or the strategies used while learning. These types of conversations can build students' declarative metacognitive knowledge and promote reflection on ideas that might not have been previously considered.

Both explicit and implicit metacognition instruction are considered important (Joseph, 2009; Paris \& Paris, 2001; Paris \& Winograd, 2003; Pintrich, 2002; Veenman et al., 2006), but research shows that teachers use explicit instruction less frequently than implicit instruction (Veenman, 2011). One study found that only $15 \%$ of teachers' strategy instructions were explicit (Kistner et al., 2010). This is potentially problematic because evidence suggests that explicit strategy instruction is related to gains in student achievement, whereas implicit instruction is not (Kistner et al., 2010). One possible explanation for the different impacts of implicit and explicit instruction can be illustrated by a toolbox analogy. Metacognition can be thought of as a set of tools that students may use in various ways when engaging in learning tasks. Implicit instruction reminds students to make use of the tools in their toolbox, whereas explicit instruction provides students with new tools. If a student already has a particular tool at his disposal, implicit instruction simply promotes continued use of that tool. However, if the student does not have the tool that is being prompted or modeled, the implicit instruction is unlikely to lead to the student using that particular tool. In this case, explicit instruction could provide the student with that particular tool, so that it may be used in the future. From this view, it is likely the addition of new tools to the toolbox (via explicit instruction) that leads to gains in student achievement.

Metacognition instruction often involves teaching students strategies, and in such cases is often referred to as strategy instruction. Strategies are procedures that can facilitate learning or the completion of a task, but 
do not necessarily have to be used. Metacognition instruction related to strategies can include explicitly providing direct instruction on how and when to use the strategy or discussing the benefits of using the strategy, as well as implicitly prompting students to use the strategy and modeling the strategy. Well-known strategies that can be taught explicitly include note taking (Lee, Lan, Hamman, \& Hendricks, 2008), planning strategies such as outlining (Kellogg, 1988), memory strategies such as mnemonics (Johnson \& Obi, 1993), and various reading comprehension strategies such as previewing the text, asking questions, and identifying the text structure (Blachowicz \& Ogle, 2001). Other helpful strategies that can be taught explicitly include creating graphic organizers (such as the matrix presented in the opening example; see Kiewra, 2004), self-testing, summarizing, and self-monitoring.

\section{Principles for Effective Metacognition Instruction}

Three general principles for implementing effective metacognition instruction have been identified (Veenman, 2103; Veenman et al., 2006). First, Veenman proposes that instruction should be embedded into an authentic learning context. Although metacognition could be taught independent of other content, it is most effective when presented concurrently with course material. Embedded presentation allows students to connect the metacognitive knowledge or skills to an authentic learning task. Thus, students see how metacognition can aid their performance in that specific context. For example, an elementary teacher could talk to students about self-monitoring their understanding in conjunction with a specific mathematics lesson and then prompt students self-monitor their understanding during the lesson and subsequent practice activities. Ideally, students' self-monitoring judgments would be shared with the teacher and connected to performance (e.g., completion of practice problems) so that the teacher could provide students with feedback on their monitoring accuracy.

An additional benefit of embedding metacognition instruction is that it can build conditional metacognitive knowledge because students are exposed to the conditions under which a skill or strategy should be used. It can be helpful to explicitly discuss the conditions that should cue students to the need for a strategy because conditional knowledge makes strategy transfer possible. This conditional knowledge is critical because the primary value of strategies is that they can be used in multiple situations. In 
the opening scenario, both Mr. Brown and Ms. Andrews embedded metacognition instruction into the lesson about the founding fathers. The students were able to learn and practice the matrix-organizer strategy during an authentic learning task. Ideally, those students would later recognize that they benefitted from using the strategy, and they would be motivated to use the strategy again when completing a similar task.

Veenman's second principle states that metacognition should be taught using what is referred to as informed training (Campione, Brown, \& Ferrara, 1982; Veenman, 2013; Veenman et al., 2006). Informed training involves explaining the benefits of using metacognition, and it is represented as "Teaching Benefits" in the taxonomy of metacognition instruction (Figure 3). Understanding such benefits motivates students to use metacognition and increases their expectations of success. This motivation is important because learning and mastering new strategies is an effortful process, and sometimes the benefits of using the strategy are not immediately clear. For example, a high school history teacher might teach her students to pause while reading and mentally summarize each section in the textbook in order to promote comprehension and retention of the information. If the students are not told that this strategy promotes comprehension and retention, the students are likely to believe the strategy is a waste of time, and as a result they will not use the strategy. However, if the teacher explains that pausing to summarize the text can increase what is learned, reduce the amount of time needed for restudying, and improve their performance on quizzes and tests, the students are more likely to be motivated to use the strategy. Ms. Andrews used an informed training approach in the opening scenario when she described how the matrix organizer would help the students learn and prepare for the upcoming test. Because she explained how the matrix organizer could contribute to their learning, Ms. Andrews' students are more likely to use the strategy even if they are not required to do so.

Veenman's last principle of metacognition instruction is prolonged training. The acquisition of metacognitive skills and knowledge is a longterm process, and any efforts to foster metacognition should extend over several weeks and months. Generally speaking, the longer the training, the better results will be (Dignath \& Büttner, 2008; Veenman, 2013). For example, a teacher interested in providing note-taking instruction to middle school students is more likely to see long-term improvements in note taking if instruction and feedback take place over the course 
of a semester rather than over only a few days. With prolonged training, instruction should initially be primarily explicit, but over time as students begin to master the strategy, implicit instruction may become more common.

\section{Steps for Embedding Metacognition Instruction}

As described above as part of Veenman's first principle (Veenman, 2013; Veenman et al., 2006), embedded metacognition instruction is metacognition instruction that presented within course content, rather than separate from focal learning activities. Effective embedded metacognition instruction of skills and strategies can be broken down into five steps. ${ }^{1}$

1. Introduce: present the skill or strategy, describe what it is and how it can be used, and demonstrate it.

2. Sell: explain the benefits of intentional use.

3. Generalize: elaborate on how the skill or strategy can be used in other contexts.

4. Practice: provide specific and structured opportunities for students to practice the skill or strategy.

5. Feedback: provide guidance on strategy use, and make corrections as necessary.

Ideally, steps 3, 4, and 5 would be part of an ongoing cycle, where students are regularly presented new situations where the skill or strategy is useful (Generalize), prompted to use the skill or strategy (Practice), and provided corrective feedback when appropriate (Feedback).

Embedded metacognition instruction related to metacognitive knowledge involves fewer steps than metacognition instruction of skills and strategies. Metacognitive knowledge can be fostered by (a) Introducing topics related to metacognitive knowledge, such as individual strengths in weaknesses, recognizing someone else's viewpoint, and taking time to think about whether or not new information was fully understood, and (b) allowing time for Reflection related to metacognitive ideas. Metacognitive knowledge is built through reflection (Tarricone, 2011), but reflection is unlikely to occur spontaneously. Structured opportunities for reflection,

1. The five steps presented here are based on Kiewra's (2009) four steps of strategy instruction 
such as those provided through discussion, journaling, or other writing activities can increase the likelihood that students will engage in meaningful reflection that will lead to increased metacognitive knowledge.

\section{Conclusion}

In the opening example, the American history teachers varied considerably with regard to the amount of metacognition instruction they provided. Ms. Andrews used explicit instruction that provided students with the procedural and conditional knowledge they would need to use the matrix-learning strategy for the present assignment and future assignments too. In general, explicit instruction is not seen as frequently as implicit instruction (like that of Mr. Brown), but many teachers do use both implicit and explicit instruction while teaching. In order for metacognition instruction to be effective, it should be embedded within authentic learning contexts, include instruction on the benefits of metacognition, and be ongoing. The steps for embedding both explicit and implicit instruction presented in this article provide educators with a starting point for incorporating more metacognition instruction into their teaching. By providing metacognition instruction of strategies, metacognitive knowledge, and metacognitive skills, teachers can help students be more strategic and independent learners.

\section{References}

Blachowicz, C., \& Ogle, D. (2001). Reading comprehension: Strategies for independent learners. New York, NY: The Guilford Press.

Campione, J.C., Brown, A.L., \& Ferrara, R.A. (1982). Mental retardation and intelligence. In R.J. Sternberg (Ed.), Handbook of human intelligence (pp.392490). Cambridge: Cambridge University Press.

Clift, R. T., Ghatala, E. S., Naus, M. M., \& Poole, J. (1990). Exploring teachers' knowledge of strategic study activity. Journal of Experimental Education, 58, 253-263.

Csíkos, C., \& Steklács, J. (2010). Metacognition-based reading intervention programs among fourth-grade Hungarian students. In A. Efklies \& P. Misailidi (Eds.), Trends and Prospects in Metacognition Research (pp. 345-366). New York, NY: Springer Science Business Media. 
Dignath, C., \& Büttner, G. (2008). Components of fostering self-regulated learning among students. A meta-analysis on intervention studies at primary and secondary school level. Metacognition and Learning, 3(3), 231-264.

Dignath-van Ewijk, C., Dickhäuser, O., \& Büttner, G. (2013). Assessing How Teachers Enhance Self-Regulated Learning: A Multiperspective Approach. Journal of Cognitive Education and Psychology, 12(3), 338-358.

Dignath-van Ewijk, C., \& van der Werf, G. (2012). What Teachers Think about Self-Regulated Learning: Investigating Teacher Beliefs and Teacher Behavior of Enhancing Students' Self-Regulation. Education Research International, 2012.

Durkin, D. (1978). What classroom observations reveal about reading comprehension instruction. Reading Research Quarterly, 481-533.

Flavell, J. H. (1979). Metacognition and cognitive monitoring: A new area of cognitive-developmental inquiry. American Psychologist, 34(10), 906.

Flavell, J. H. (1992). Perspectives on perspective taking. In H. Beilin \& P. Pufall (Eds.), Piaget's theory: Prospects and possibilities, (pp. 109-139). Hillsdale, NJ: Erlbaum.

Haller, E. P., Child, D. A., \& Walberg, H. J. (1988). Can comprehension be taught? A quantitative synthesis of "metacognitive" studies. Educational Researcher, 17(9), 5-8.

Hamman, D., Berthelot, J., Saia, J., \& Crowley, E. (2000). Teachers' coaching of learning and its relation to students' strategic learning. Journal of Educational Psychology, 92(2), 342.

Hargrove, R. A., \& Nietfield, J. L. (2015). The impact of metacognitive instruction on creative problem solving. The Journal of Experimental Education, 83(3), 291-318.

Hilden, K. R., \& Pressley, M. (2007). Self-regulation through transactional strategies instruction. Reading \& Writing Quarterly, 23(1), 51-75.

Huff, J. D., \& Nietfeld, J. L. (2009). Using strategy instruction and confidence judgments to improve metacognitive monitoring. Metacognition and Learning, 4(2), 161-176.

Jacobs, J. E., \& Paris, S. G. (1987). Children's metacognition about reading: Issues in definition, measurement, and instruction. Educational Psychologist,22(3-4), 255-278.

Johnson, D., \& Obi, S. C., (1993). Mnemonics: Can you spell it?. (ERIC Document Reproduction Service No. ED394220). Retrieved from http://eric. ed.gov/?id=ED394220

Joseph, N. (2009). Metacognition needed: Teaching middle and high school students to develop strategic learning skills. Preventing School Failure: Alternative Education for Children and Youth, 54(2), 99-103. 
Kellogg, R. T. (1988). Attentional overload and writing performance: Effects of rough draft and outline strategies. Journal of Experimental Psychology: Learning, Memory, and Cognition 14(2), 355-365.

Kiewra, K. A. (2005). Learn how to study and SOAR to success. Upper Saddle River, NJ: Pearson, Prentice Hall.

Kiewra, K. A. (2009). Teaching how to learn: The teacher's guide to student success. Thousand Oaks, CA: Corwin Press.

Kistner, S., Rakoczy, K., Otto, B., Dignath-van Ewijk, C., Büttner, G., \& Klieme, E. (2010). Promotion of self-regulated learning in classrooms: investigating frequency, quality, and consequences for student performance. Metacognition and learning , 5(2), 157-171.

Krebs, S. S., \& Roebers, C. M. (2010). Children's strategic regulation, metacognitive monitoring, and control processes during test taking. British Journal of Educational Psychology, 8o(3), 325-340.

Labuhn, A. S., Zimmerman, B. J., \& Hasselhorn, M. (2010). Enhancing students' self-regulation and mathematics performance: the influence of feedback and self-evaluative standards. Metacognition and Learning , 5(2), 173-194.

Lee, P.-L., Lan, W., Hamman, D., \& Hendricks, B. (2008). The effects of teaching notetaking strategies on elementary students' science learning. Instructional Science 36(3), 191-201.

Moely, B. E., Hart, S. S., Leal, L., Santulli, K. A., Rao, N., Johnson, T., \& Hamilton, L. B. (1992). The teacher's role in facilitating memory and study strategy development in the elementary school classroom. Child Development, 63(3), 653-672.

Moshman, D. (2011). Adolescent rationality and development: Cognition, morality, and identity. Taylor \& Francis.

Pape, S. J., Bell, C. V., \& Yetkin, I. E. (2003). Developing mathematical thinking and self-regulated learning: A teaching experiment in a seventh-grade mathematics classroom. Educational Studies in Mathematics, 53(3), 179-202.

Paris, S. G., \& Paris, A. H. (2001). Classroom applications of research on self-regulated learning. Educational Psychologist, 36(2), 89-101.

Paris, S., \& Winograd, P. (2003). The Role of Self-Regulated Learning in Contextual Teaching: Principles and Practices for Teacher Preparation. Retrieved November 5, 2012.

Perry, N. E. (1998). Young children's self-regulated learning and contexts that support it. Journal of Educational Psychology, 9o(4), 715-729. doi:10.1037/0022-0663.90.4.715

Perry, N. E., \& VandeKamp, K. J. (2000). Creating classroom contexts that support young children's development of self-regulated learning. International Journal of Educational Research, 33(7), 821-843. 
Perry, N. E., VandeKamp, K. O., Mercer, L. K., \& Nordby, C. J. (2002). Investigating teacher-student interactions that foster self-regulated learning. Educational Psychologist, 37(1), 5-15.

Pintrich, P. R. (2002). The role of metacognitive knowledge in learning, teaching, and assessing. Theory into practice, 41(4), 219-225.

Ramdass, D., \& Zimmerman, B. J. (2008). Effects of self-correction strategy training on middle school students' self-efficacy, self-evaluation, and mathematics division learning. Journal of advanced academics, 2O(1), 18-41.

Schraw, G. (1998). Promoting general metacognitive awareness. Instructional Science, 26, 113-125.

Schraw, G., Crippen, K. J., \& Hartley, K. (2006). Promoting self-regulation in science education: Metacognition as part of a broader perspective on learning. Research in Science Education, 36(1-2), 111-139.

Schraw, G., \& Moshman, D. (1995). Metacognitive theories. Educational Psychology Review, 7(4), 351-371.

Swanson, H. L. (1990). Influence of metacognitive knowledge and aptitude on problem solving. Journal of educational psychology, 82(2), 306.

Tarricone, P. (2011). The taxonomy of metacognition. Psychology Press.

van der Stel, M., \& Veenman, M. V. (2010). Development of metacognitive skillfulness: a longitudinal study. Learning and individual differences, 2O(3), 220-224.

Veenman, M. V. J. (2011). Learning to self-monitor and self-regulate. In R. Mayer \& P. Alexander (Eds.), Handbook of research on learning and instruction (pp. 197-218). New York: Routledge.

Veenman, M. V. J. (2013). Training metacognitive skills in students with availability and production deficiencies. In J. Bembenutty, T. Cleary \& A. Kitsantas (Eds.), Applications of self-regulated learning across diverse disciplines (pp. 299-324). Charlotte, NC: Information Age Publishing, Inc.

Veenman, M. V., \& Spaans, M. A. (2005). Relation between intellectual and metacognitive skills: Age and task differences. Learning and Individual Differences, 15(2), 159-176.

Veenman, M. V., Van Hout-Wolters, B. H. A. M., \& Afflerbach, P. (2006). Metacognition and learning: Conceptual and methodological considerations. Metacognition and learning, 1(1), 3-14.

Veenman, M. V., Wilhelm, P., \& Beishuizen, J. J. (2004). The relation between intellectual and metacognitive skills from a developmental perspective. Learning and instruction, 14(1), 89-109.

Wang, M. C., Haertel, G. D., \& Walberg, H. J. (1990). What influences learning? A content analysis of review literature. The Journal of Educational Research, $30-43$. 
Young, A., \& Fry, J. (2012). Metacognitive awareness and academic achievement in college students. Journal of the Scholarship of Teaching and Learning, 8(2), 1-10.

Zimmerman, B. J. (2000). Attaining self-regulation: A social cognitive perspective. In M. Boekaerts, P. R. Pintrich \& M. Zeidner (Eds.), Handbook of selfregulation (pp. 13-39). San Diego: Academic Press.

Zumbrunn, S., Tadlock, J., \& Roberts, E. D. (2011). Encouraging self-regulated learning in the classroom: A review of the literature. Metropolitan Educational Research Consortium, 1-28. 